\title{
OPPORTUNITIES AND CHALLENGES OF CONTEMPORARY CORRUPTION RESEARCH: AN INTERVIEW WITH DONATELLA DELLA PORTA
}

\author{
Felippe CLEMENTE \\ Luís DE SOUSA \\ Luciana Alexandra GHICA
}

\begin{abstract}
This is an edited and revised version of an interview recorded in September 2021, which served as closing remarks for the $3^{\text {rd }}$ edition of the Research Methods School on Corruption and Anti-Corruption Analysis (CORAN), Institute of Social Sciences, University of Lisbon (Portugal), 27-30 September 2021. The event was organized jointly with the Centre for International Cooperation and Development Studies (IDC) of the University of Bucharest, as part of the $7^{\text {th }}$ edition of the International Interdisciplinary Conference of Political Research SCOPE: Science of Politics. The notes and specific references were added to support especially younger researchers who may not be very familiar with the field or with certain past events.
\end{abstract}

Keywords: corruption, political corruption, definitions of corruption, corruption studies, court cases, criminal investigations, scandal, methodology, legal protection of scholars, deregulation, super-rich, impact of COVID-19

Donatella DELLA PORTA is currently Professor of political science, Dean of the Faculty of Political and Social Sciences, and Director of the doctoral program in Political Science and Sociology at the Scuola Normale Superiore in Florence, where she also leads the Center on Social Movement Studies (Cosmos). Previously, she held research and/or teaching positions at several institutions, including the European University Institute (EUI) Florence and the University of Florence (Italy), Cornell University (USA), Wissenschaftszentrum Berlin für Sozialforschung (Germany) and the Fondation Nationale des Sciences Politiques (France). As author or editor of more than 90 books, 150 articles and 150 contributions in edited volumes, and as Principal Investigator of major European research grants and programs, she contributed significantly to the development of several research areas at the intersection of political science and sociology, especially social movements, corruption, political violence, terrorism, police and protest policing, civil society and democratization. Throughout her career she received numerous awards and distinctions, including the ECPR Mattei Dogan Prize for distinguished achievements in the field of political sociology (2011) and the Forschungspreis of the Alexander von Humboldt Foundation, as well as several honorary degrees. Since 2015 she is Doctor Honoris Causa of the University of Bucharest.

Luís DE SOUSA: Thank you very much for having accepted our invitation. You are a reference to many scholars, not just in the field of corruption (Della Porta \& Vannucci 2012; Della Porta \& Vannucci 2007; Della Porta \& Rose-Ackerman 2002; Della Porta \& Vannucci 1999; Della Porta \& Mény 1997), but in so many other fields, most notably social movements and protest (Della Porta 2009b; Della Porta \& Caiani 2009; Della Porta 2007; Della Porta \& Diani 2006; Della Porta \& Tarrow 2005; Della Porta, Kriesi \& Rucht 1999; Della Porta \& Diani 1999), extreme right (Caiani, Della Porta \& Wagermann 2012), democracy (Della Porta 2013a; Della Porta \& Rucht 2013; Della Porta 2011), party politics (Della Porta 2009c) and local (Della Porta 2006; Della Porta 2004), regional (Della Porta 2009a; Della Porta \& Caiani 2006) and global governance (Della Porta et al. 2006; Smith et al. 2007; Smith et al. 2014). There are also topics on which you wrote many years ago, during the early days of your career, such as terrorism and political violence (Della Porta 1995; Della Porta \& Pasquino 1983; Della Porta 
1990), and that you have brought back to debate in recent publications (Della Porta 2013b). You are also known for your work on research methods in social and political sciences (Della Porta 2014; Della Porta \& Keating 2008; Della Porta 2002; Cotta, Della Porta \& Morlino 2001), which has been handy to many students. This is an incredible array of subjects. Your first major work on corruption - Lo scambio occulto: Casi di corruzione politica in Italia [The opaque exchange: Cases of political corruption in Italy] (Della Porta 1992) was published three decades ago, the very same year that the Tangentopoli investigations kicked off with the arrest of Mario Chiesa ${ }^{1}$ in Italy. These investigations had a spill over effect to the rest of Europe. Everybody was following these developments taking place in Italy. So, naturally, I would like to ask you first what made you dive into this very complex subject in a country that is also quite complex in terms of politics and society. Also, how developed was research around such topics, in Europe, back then?

Donatella DELLA PORTA: Thanks a lot for this interview and thank you for the possibility to develop my thoughts about political corruption. One of the main reasons why I started to work on political corruption was that, as a political scientist, as well as a political sociologist looking at Italy in the 1980s and early 1990s, it was impossible not to consider corruption. Even before I started doing empirical research on the topic as a scholar, as a simple citizen I had the impression that there was a visible world of politics that counted very little and there was also an invisible world, of hidden exchanges, that we knew little about. At that time, I had been already working on other types of phenomena that were not usually addressed by mainstream political scientists, but which I believed exerted a strong impact on institutional politics. I was working, for instance, on social movements, which I considered to be mainly the progressive and positive side of politics, while political corruption was its dark side. And I thought that this was so much embedded in institutional politics that it was not possible to think about the Italian political parties or the Italian government, at local or central level, without considering these hidden exchanges. In fact, one of the first pieces on which I worked together with Alberto Vannucci singled out the types of political actors that corruption brings to the surface (Della Porta \& Vannucci 1994). This is how we started to ask how the normal, visible type of structures within the political system had been gradually transformed by the arrival of business politicians.

Was this type of research widespread at that time? Not at all, at least not at all in Italy. In Europe in general, it was also a field that was considered and analysed mainly in connection to development and the Global South as we would say nowadays. Even in countries for instance in southern Europe, where the perception that corruption was very widespread, there was very little sociological research. In Lo scambio occulto... that you already mentioned (Della Porta 1992), I analysed in depth three cases of corruption. However, at that time, it had been very challenging to find these cases, especially to find sources that I could use to document and analyse them. Eventually, I finished the book - it was a sort of luck for me, and luck for the country - exactly when the "Mani Pulite" investigations started. They happened roughly around the same time with the publication of my book, so I could not get the ongoing investigations too much into account. However, while I was doing research for the book, I had been in contact with judges that were investigating political corruption. Therefore, I could also understand better how that side of anti-corruption worked.

Luciana Alexandra GHICA: You often used legal documents, legal materials, and court cases when you tried to dissect and understand through the lenses of sociological analysis the anatomy of corruption, its actors, the resources. Sometimes as scholars, we tend to consider such documents as more accurate when collecting data, although this is not necessarily true. We also find them convenient because they should not be very difficult to access, at least in a democracy. However, even when we have the best possible conditions for access to extensive quality data from legal materials, these sources have limitations. You used this type of data, but also other methods of data collection and investigation. In your view, which are the main challenges and risks associated with corruption research from the perspective of the sources to which we can have access?

\footnotetext{
1 "Mani Pulite" (eng. "Clean hands") were a series of judicial investigations on political corruption that took place in Italy in the 1990s, following the arrest of Italian Socialist Party member Mario Chiesa for accepting a bribe from a company. Left politically isolated and publicly humiliated, he started to provide information that revealed a much more complex system and network of political corruption. This system was often referred to in the media as Tangentopoli (eng. "Bribesville"). For further details on these matters, see for example Della Porta \& Vannucci (2012).
} 
Donatella DELLA PORTA: Of course, each source has its own bias. Indeed, I attempted to develop this sort of methodological pluralism in addressing empirical research on political corruption in order to try to reduce those biases. I have used various types of databases that have been used also by other scholars, such as the Transparency International's Corruption Perception Index, as well as other different statistical data. But they were not so useful in addressing the main research questions that I was raising, which were primarily focusing on the how and not so much on the root causes. Of course, the why was always in the background. What I tried to do was to map and describe the way in which corrupt exchanges developed. In fact, in this first book, Lo scambio occulto..., for the three cases I used available judicial materials, but I also interviewed different actors, including the corrupt agents. And this was interesting because what I also wanted to analyse was the social construction of corruption. How does it happen that an entire system is corrupt? Since corrupt agents do not perceive themselves as criminals, how do they justify their actions? The issue of the moral costs of corruption is key to research on political corruption, but often in an abstract way. Instead, I wanted to investigate how the systems of exchange worked. This is how I started to look at corruption as a complex exchange, focusing not only on the transaction between those who bribed and those who were bribed, but also on how corrupt politicians and those who gave money to them were interconnected in a complex network of relations, including party defectors, party factions and so on. To address these research questions, I triangulated the judicial sources with interviews with different types of people. I interviewed trade unionists, party members, businesspeople, and other stakeholders. What was also important in this first attempt was to choose cases in which I knew I could rely upon a sort of network of trust. Just to give an example, one such case of corruption took place in Catania, Sicily, my hometown. This allowed me to start the fieldwork with some connections for expert interviews. Developing a relationship of trust with one's sources is extremely important. However, it takes time, and it may be challenging. Another case took place in Florence, where I live. There, I also started by relying first upon a network of contacts. The judicial material is interesting, there are different types of documents and data, but of course they are biased in the sense that judges are only interested in legal liability, whereas I was more interested in reconstructing the political system in general and mapping and understanding the system of corruption within this broad set of exchanges.

Luís DE SOUSA: In fact, you showed in your analyses that corruption was not just a quid pro quo exchange. The unveiled cases were very complex. You also identified issues related to political protection. Even journalists or NGOs could be involved in those schemes, to camouflage or whiten some practices. You really had to go beyond what the judges investigated in court cases to understand the complexity of this phenomenon.

Donatella DELLA PORTA: Yes, definitely. Of course, the court cases are still very important because they aggregate facts and compile different materials, from different sources. It is also interesting to see how the capacity to conduct criminal investigations has changed over time, for instance, with the availability of new technologies and how these also changed the type of sources that we can access. In our last book (Della Porta \& Vannucci 2021), we also made use of court cases, but the type of information changed a lot, because investigations now make increasing use of sophisticated methods of communications surveillance, such as mobile phone tapping, internet monitoring, and other intrusive technologies. In short, not just interrogations, but also recordings, telephone calls and so on. This offers quite a rich and more complex type of information than the interrogation or questioning of the people involved in the corrupt exchanges.

Another thing that is important to consider when reflecting upon the potential biases of the sources that one uses for research on corruption is the strategies used by different actors. For instance, in Italy, during the "Mani Pulite" investigations, one of the strategies used by judges was to obtain information from businesspeople. This led to classifying cases as crime of extortion (it. "concussione") rather than corruption (it. "corruzione"). This meant charging politicians, rather than businesspeople, with the latter portrayed as victims. We (and I say "we", because I work on such matters with Alessandro Pizzorno, Alberto Vannucci and other colleagues) considered that this was a distortion of 
reality since businesspeople were highly involved in building cartels and so on. In fact, in the second wave of corruption investigations (i.e., post "Mani Pulite"), all these figures re-emerged as increasingly central because they had kept their own social capital. I used the term "negative social capital" to characterise those situations in which social capital (as trust and reciprocity) is used to maintain the system of corruption intact (Della Porta 2000). In this context, I think it is worth considering more carefully the strategies of each of the parties involved, including the strategies of judges and other state authorities. There is a lot of research done on the bias of police data, of legal databases and, of course, of media sources. Triangulating them is a way to reduce their specific biases.

Luciana Alexandra GHICA: You mentioned triangulation as a means that you used to tackle the risk of bias in your own research, but were there other risks that you faced or that were present in this field, maybe not necessarily targeting you directly, but often experienced by scholars who are investigating corruption? And are they really significant?

Donatella DELLA PORTA: Well, yes. One must be very careful because many of the corrupt people have good lawyers and money to invest. We also must consider that, as a profession, in such matters social scientists are much less protected than journalists, for instance, or judges. One of the things that we did was to be extremely careful when mentioning names. This was not only to protect ourselves against potential libel charges, but also because we wanted to reconstruct a sociological system of exchanges, without focusing the attention on specific people. Of course, for instance in my analysis of the three cases in Lo scambio occulto... (Della Porta 1992), I could not always keep the involved people anonymous. In fact, one of the persons named in the book threatened the publisher (Il Mulino). Eventually, that person could not do anything because all the information was related to solid evidence. Avoiding naming people is possible if the names are not necessary to describe and analyse specific dynamics. It is also a good strategy, not only to protect yourself from this type of incidents, but also to avoid giving the impression that you are investigating a criminal case, especially since the police and the judiciary have more information than social scientists for investigating a specific case. What we want to do as scholars is to reconstruct the system of exchanges. In fact, in all my books and articles in which such situations may be represented, I always included a note clarifying that my intention was not to reconstruct the legal responsibility of specific individuals, but to sociologically analyse the net of corrupt exchanges.

Are there other challenges common for research on corruption and related topics? I would advise young scholars to try not to get lost in the details but rather to keep focused on the sociological concepts, the sociological processes and so on. Another specific concern is related to the fact that, whether we like it or not, our research may be used by others in a distorted way. For that reason, I think one must be careful when intervening as a sort of public intellectual so that the scholarly work is not misused. To give you an example, in the investigations against the former Brazilian President Luiz Inácio Lula da Silva and his collaborators, a judge referred to the work that I and Alberto Vannucci did (Della Porta \&Vannucci 2012). The judge then became part of the government of the current President Jair Bolsonaro, a rival of Lula da Silva, and was eventually charged of having produced fake evidence for political reason. I consider such situations quite risky exactly because there was a political agenda behind. Of course, there was not much I could do except saying that I am not coming to present the book with these persons and trying to redress wrong interpretations in the press. I think this should be a general concern to keep in mind when working on politically sensitive issues such as corruption or terrorism, where different interests often interact in the public arena.

Felippe CLEMENTE: Inevitably, the case that you mentioned brings into the discussion the issue of populism, as this is the framework through which contemporary Brazilian politics has been often studied. But, in recent years, the issue of corruption has also been closely associated to that of populism in the public debate and, to an extent, in academic works, in more cases than the Brazilian one. Do you feel this may drive young researchers away from the study of corruption? Is there a subject fatigue/exhaustion? 
Donatella DELLA PORTA: Well, I do not think that this is a zero-sum game in which you can focus on populism without considering corruption. One of the core issues of the populist discourse is the instrumentalization of charges of corruption and the declining trust in the political institutional system. What I think needs to be considered is that corruption tends to adapt to different types of systems. For instance, Italy in the 1980s was considered the opposite of a populist system. It was a partytocracy (it. "partitocrazia"). In fact, I think this term was coined to describe the Italian context: strong parties with mass membership and strong control on political institutions, on public policies, allocation of state resources and so on. My research findings highlighted, even before the "Mani Pulite" investigations, that corruption tended to challenge the power of political parties, in their classical forms as ideological mass party. Some parties played, however, an important role as brokers of political corruption. In particular, in the late 1980s, there was an attempt of the main political parties, mainly the Italian Socialist Party and the Christian Democratic Party, to develop a sort of very structured system of illicit party and personal financing, in which bribes were collected by party financial officers and then distributed according to a predefined set of criteria. Eventually, this system collapsed because, as investigations on organized crime demonstrate, the use of hidden exchanges tends to produce centrifugal tendencies, unless one has very strong resources to impose the terms of exchange through coercion and violence. In the Craxi's model ${ }^{2}$ there was the aspiration to create a perfectly centralized system of corruption, but in fact the parties were transformed and weakened from within. When investigations on political corruption started, there was the impression that the system collapsed suddenly - like a house of cards. However, in reality, the parties had been already weakened from within, they were already fragmented, they were losing trust from the members that were not involved in the corrupt exchange and so on.

In short, I think that there are many ways to connect research on populism and political corruption. There are however also risks to avoid. Sometimes research on populism considers corruption only as a discursive frame. It is the framing of the struggle between those from below (the "people") and those from above (the "elites"), and corruption is seen as a sort of misleading or constructed concept that populist leaders use to attack the latter. This, of course, is part of the game. But corruption is not just talk; it is also something very real, and therefore framing it as a challenge for democracy is often not just populist rhetoric. Moreover, we must take into consideration that populism is quite a blurred concept used to describe different types of phenomena across different political systems. For instance, it has been used to refer to radical-right populism in countries where there was little reported corruption. So, corruption was understood in a broader way, as giving up on fundamental values. To wrap up, I think that one should be careful when looking at the link between populism and corruption, because corruption is not just a sort of frame used to attack the elites. Indeed, elites can be very corrupt, and this should also be investigated.

Luciana Alexandra GHICA: In contemporary political science, particularly in the studies that are of comparative nature or take into account international dimensions, we are increasingly becoming aware of the limitations of the conceptual tools that we have been using for decades for making sense of social and political phenomena. Most of our theoretical and conceptual frameworks were developed during the Cold War, in the so-called Global North, within the Cold War logic or in a very confrontational, "big powers", asymmetrical, sometimes also very dichotomic and ideologized way of thinking about the world. And the more we are studying at larger scales, not just larger sets of data, but looking at more cases across the globe, we realize that these theoretical and conceptual frameworks are unsatisfactory for the advancement of knowledge. Would you say that this applies also in the case of corruption research? Do we need new concepts or new conceptual developments when we are framing or researching corruption?

Donatella DELLA PORTA: First of all, the political situation is changing very quickly. Therefore, ideological concerns are re-emerging. Just to refer to a recent piece of news, the US President Joe Biden said that the troops must be withdrawn from Afghanistan and then we should all focus on the new big battle against Russia and China. This is not a peaceful world. This is a world system in which new

\footnotetext{
2 Benedetto "Bettino" Craxi, a former Prime Minister of Italy (1983-1987), was one of the most high-profile politicians convicted for corruption and illicit party financing, following the "Mani Pulite" investigations.
} 
enemies are singled out. In this context, corruption can be used as a sort of instrument for various types of international interventions. The struggle against corruption has been actually used by different international actors to pursue aims that are not only or necessarily related to good governance but rather address other, less noble political goals. The fight against corruption appears often as part of international conditionality in fund-supported programmes directed at developing countries. Corruption is often presented as related to state powers, the public sector, and state interventions in the economy and so on. This has been used to justify the adoption of neoliberal types of policies, such as liberalization, privatization, and deregulation. In our last book with Alberto Vannucci (Della Porta \& Vannucci 2021), we alerted to the fact that liberalization, privatization, and market deregulation policies, not only fail to reduce corruption, but can also transform its nature and scope by making it more rampant. Such policies tend to lead to more corruption because of two reasons. One has to do with the lack of state capacity to detect and sanction serious wrongdoing in the private sector. In a privatized, deregulated, liberalized market there are fewer instruments to prosecute private forms of corruption, which tend to be legalized and/or harder to detect. The other issue has more to do with the level of moral costs for the society. The more these types of anti-corruption interventions are framed by a simplistic moral discourse that tends to describe the public as "dirty" and the market as "clean", the more it contributes to diminishing the symbolic value of the commons, of public goods and so on. This is also an element that we believe may fuel corruption rather than limiting it.

About the ways in which we define our concepts to describe and analyse contemporary political and social processes, if we look at the legal definitions of corruption, they often seem unable to capture the varieties of this phenomenon that are more related with the creation of oligarchies and plutocracies, i.e., economic elites overlapping with institutional elites. Cases such as Silvio Berlusconi or Donald Trump or many others by now, as well as the Panama Papers are typical examples of this type of connections. They have been identified as quite relevant also in countries, such as Iceland, that have been considered for a long time to be corruption-free. That is why some legal experts are also trying nowadays to suggest broadening the definition of corruption beyond the exchange of bribes. There are also many areas that provide food for thought on such matters. For example, I am currently involved in a research project on the so-called super-rich. It often happens that the super-rich criticize politics, but they also use politics to forward their interests, they donate money to parties and candidates, and they intervene to protect their own capital - for instance, to protect their economic capital from taxes. They develop a specific type of ethos, which is not related to public ethics, but to the legitimacy of competition and to distorted perspectives on merit. One should investigate these cases in which corruption is not an exchange of bribes for favours, but it is the use of money in order to unduly influence public decisions. Of course, there are many ways in which private interests can influence public decisions. For instance, interest groups may attempt to advance their perspectives on certain policy matters in a legitimate manner, and contribute to a more informed policy-making. But the cases mentioned above are often at the limit of legality and transparency.

Luís DE SOUSA: There is an emerging literature that tries to address legal/institutional corruption, practices and policies that, as you said, are on the borderline of legality and transparency. In most instances, such cases would not qualify as criminal offences, but they are still ethically problematic. It is complicated but important to study these practices because, as you mentioned, the question touches upon issues of policy capture, collusion between political and business interests, and we are witnessing more of this kind of corruption in recent years. Do you feel that this has reopened the Pandora's box of the definition of corruption?

Donatella DELLA PORTA: Well, I think that Pandora's box was always open to a certain extent. Of course, we could rely on the legal definition. But we must also acknowledge that when we do comparative research, we must deal with very different legal systems. Something that is a crime in Italy may not be classified as a crime in other countries. That is why, in order to be able to understand how embedded this phenomenon is, we need to increasingly connect research on corruption with research on normal politics, normal market development and so on. This implies to go beyond bribes. Already in my definitions of hidden exchange, I tried to go beyond the act of bribing because I thought that corruption was also about the deviant ways in which democracy functioned. Keeping things hidden is an indicator of the corruption of democracy, of the way in which democracy normally works. 
The current pandemic is particularly relevant for this matter. Something that we could do together as scholars in this field is to start looking at the link between (responses to) pandemics and corruption. We are already doing some work on the public bids related to the management of the pandemic, as part of a research project focusing on the Italian case. These public procurement processes have been extremely problematic in many countries, including in Germany, a country which is often considered as very rigorous in the way public money is spent and unproblematic when it comes to corruption. Very often, the ways in which corruption has developed in such cases was not through bribes, but through more complex types of exchanges, delayed exchanges involving relatives and friends of politicians in government, which show that certain governance mechanisms were already deeply corrupted. In some cases, these types of hidden exchanges, facilitated by the lack of transparency of the emergency measures, were used for personal enrichment. However, it is also important to connect these specific cases with the way in which state subsystems have developed. For instance, the privatisation of the public health system, has introduced a logic of profiteering that profoundly transformed the ways in which that system works. The pandemic has made more visible such types of effects in our society. It will be an interesting, though sad, research theme.

Luís DE SOUSA: Indeed, a good ground for research within the context of the pandemic: the special measures, the weak controls, the clientelist networks that you just mentioned, which in a lot of ways are favoured by revolving door schemes at different levels - local, regional, and state level. But there is also a dimension related to the perceptions of how much of that pandemic-related corruption has impacted on people's expectations about political processes and institutions. In Portugal, we are currently carrying out some research on this impact, both at local and national levels.

Felippe CLEMENTE: Our research involves data from a mass survey where we specifically asked citizens to what extent they believed the opportunities for corruption had grown within the context of the COVID-19 pandemic and whether they considered understandable to cut corners in public procurement processes in order to respond to the pandemic.

Luís DE SOUSA: The exceptional measures adopted and the way in which they were implemented, particularly public procurement in the health sector, accompanied by media revelations of cases of serious wrongdoing, had an impact on public opinion. To what extent this has pended negatively on their evaluations of the way the government has handled the crisis is something that we are currently still trying to understand.

We already touched upon several issues. But if we were to think also about the training of future generations of scholars in the field, more specifically if we were to build a political science curriculum for corruption and corruption control studies at the highest academic standard, what do you think we should include as subjects, as areas of interest? We have the pandemic now. That is certainly a hot issue. But what other issues would you consider to be relevant for future research in the field?

Luciana Alexandra GHICA: And if I can develop a little on that. Now we have the pandemic but, in the future, we might have other relevant phenomena. From a larger perspective, what piece of advice would you have liked to have received when you started doing research on corruption and that you would like to share with young researchers who are just embarking in this field?

Donatella DELLA PORTA: Well, a couple of considerations. One is that in political corruption studies, but also in social movements studies, avoiding becoming increasingly self-sufficient after achieving a certain amount of success may be quite challenging. When one starts to have specialized journals, specialized curricula, masters maybe, and so on, one of the risks is to close down external input and to focus on "defending the borders." I would be more for blurring the borders with research on other types of phenomena. What we are doing at the Scuola Normale Superiore in a research project financed by the Tuscan regional government is to investigate, for instance, the various types of crimes that relate to political corruption. In the Italian cases, for example, there are often connections to environmental crimes or to labour market transformations such as the exploitation of labour migrants, especially through forms of black labour market. I think it is important to understand such phenomena from larger perspectives if we want to capture the way in which corruption is corrupting the entire 
system by interacting with different forms of crime. Corruption is no longer just about corrupt politicians. Someone may be involved in different types of lawbreaking activities.

Additionally, we are trying to address anti-corruption not only in the traditional way (i.e., through analyses of institutional responses) but also to investigate anti-corruption "from below." Probably for me this was particularly relevant because it connected my interest in social movements with the interest in corruption. Yet, this is also especially relevant when reflecting about the current pandemic. Beyond the impact of the pandemic on the public opinion in general, what could be also interesting is to investigate the specific actors that are affected by specific instances of corruption. Within this context, we plan to study the way in which victims of the mismanagement of the health system have organized. And for this purpose, I found very useful the reflection on health social movements or social movements that target the health system. To give you an example, in Italy, as you probably know, during the early stages of the pandemic and especially in Lombardy, we had the deadliest wave. Coincidently, Lombardy is the region in which the processes of privatization within the health system developed more. There are now organizations of the relatives of the victims, such as old folks in care homes, who are organizing themselves to bring legal charges. What we have done in the Italian case is also to look at the connections between mafia-type of organized crime and political corruption. We need to treat political corruption not only as white-collar crimes, but as embedded in an illegal system that is influencing the institutional system in general.

Thinking further about the effects of the pandemic on the root causes of corruption, what you observed about the increased perceived opportunities for corruption related to COVID-19 in Portugal also resonates with our preliminary results. When I supervise PhD work at the Scuola Normale Superiore, I see that, in a way or another, none of my students can avoid addressing the pandemic in their work because it has a significant and multifaceted impact in different countries and different political systems. In this respect, I would also reflect more in general on the emergency of critical junctures and its effects on the transformation of the political systems. It has been observed about past emergencies, about previous big crises such as wars, that such turbulent moments could generate transformations that force states to become more responsible and more involved in finding solutions to social problems. For instance, after the Spanish flu there was a massive investment in public health systems, in increasing the responsibility of the state and so on. But this is not automatic. We could have also different types of developments. For example, we could witness the delegitimization of the political class and of politics in general. Some of the reactions to the pandemic are also related with the mistrust in public institutions, mistrust in science and so on. I think that the effects of the pandemic are still emerging. We will have to continue investigating them.

\section{REFERENCES}

CAIANI, Manuela, Donatella DELLA PORTA \& Claudius WAGERMANN. 2012. Mobilizing on the Extreme Right: Germany, Italy and the United States. Oxford: Oxford University Press.

COTTA, Maurizio, Donatella DELLA PORTA \& Leonardo MORLINO. 2001. Scienza politica. Bologna: Il Mulino.

DELLA PORTA, Donatella. 1990. Il terrorismo di sinistra. Bologna: Il Mulino.

DELLA PORTA, Donatella. 1992. Lo scambio occulto: Casi di corruzione politica in Italia. Bologna: Il Mulino.

DELLA PORTA, Donatella. 1995. Social Movements, Political Violence and the State: A Comparative Analysis of Italy and Germany. Cambridge: Cambridge University Press.

DELLA PORTA, Donatella. 2000. Social Capital, Beliefs in Government and Political Corruption. In Disaffected Democracies: What's Troubling the Trilateral Countries? eds. Susan J. Phar and Robert D. Putnam, 202-29. Princeton, NJ: Princeton University Press.

DELLA PORTA, Donatella. 2002. Introduzione alla scienza politica. Bologna: Il Mulino.

DELLA PORTA, Donatella, ed. 2004. Comitati di cittadini e democrazia urbana. Cosenza: Rubbettino

DELLA PORTA, Donatella. 2006. La politica locale: Potere, istituzioni e attori tra centro e periferia. Bologna: Il Mulino. 
DELLA PORTA, Donatella, ed. 2007. The Global Justice Movement: Cross National and Transnational perspectives. Boulder Co.: Paradigm Publishers.

DELLA PORTA, Donatella, ed. 2009a. Another Europe: Conceptions and practices of democracy in the European Social Forums. London: Routledge.

DELLA PORTA, Donatella, ed. 2009b. Democracy in Social Movements. Basingstoke: Palgrave.

DELLA PORTA, Donatella. 2009c. I partiti politici. Bologna: Il Mulino.

DELLA PORTA, Donatella. 2011. Democrazie. Bologna: Il Mulino.

DELLA PORTA, Donatella. 2013a. Can Democracy Be Saved? Participation, Deliberation and Social Movements. Oxford: Polity Press.

DELLA PORTA, Donatella. 2013b. Clandestine Political Violence. Cambridge: Cambridge University Press.

DELLA PORTA, Donatella, ed. 2014. Methodological Practices in Social Movement Research. Oxford: Oxford University Press.

DELLA PORTA, Donatella, Massimiliano ANDRETTA, Lorenzo MOSCA \& Herbert REITER. 2006. Globalization from Below. Minneapolis: The University of Minnesota Press.

DELLA PORTA, Donatella \& Manuela CAIANI. 2006. Quale Europa? Europeizzazione, identità e conflitti. Bologna: Il Mulino.

DELLA PORTA, Donatella \& Manuela CAIANI. 2009. Social Movements and Europeanization. Oxford: Oxford University Press. https://doi.org/10.1093/acprof:oso/9780199557783.001.0001

DELLA PORTA, Donatella \& Mario DIANI. 1999. Social Movements: An introduction. Oxford: Blackwell.

DELLA PORTA, Donatella \& Mario DIANI. 2006. Social Movements: An introduction, $2^{\text {nd }}$ ed. Oxford: Blackwell.

DELLA PORTA, Donatella \& Michael KEATING, eds. 2008. Approaches and Methodologies in the Social Sciences: A Pluralist Perspective. Cambridge: Cambridge University Press.

DELLA PORTA, Donatella, Hanspeter KRIESI \& Dieter RUCHT, eds. 1999. Social Movements in a Globalizing World. New York: Macmillan.

DELLA PORTA, Donatella \& Gianfranco PASQUINO, eds. 1983. Terrorismo e violenza politica. Tre casi a confronto: Stati Uniti, Germania e Giappone. Bologna: Il Mulino

DELLA PORTA, Donatella \& Dieter RUCHT, eds. 2013. Meeting Democracy: Power and Deliberation in Global Justice Movements. Cambridge: Cambridge University Press.

DELLA PORTA, Donatella \& Susan ROSE-ACKERMAN, eds. 2002. Corrupt Exchanges: Empirical Themes in the Politics and Political Economy Corruption. Baden-Baden: Nomos Verlag.

DELLA PORTA, Donatella \& Yves MÉNY, eds. 1997. Democracy and Corruption in Europe. London/Washington, D.C.: Pinter.

DELLA PORTA, Donatella \& Sidney TARROW, eds. 2005. Transnational Protest and Global Activism. New York: Rowman and Littlefield.

DELLA PORTA, Donatella \& Alberto VANNUCCI. 1994. Amministrazione publica e corruzione: Risorse, mecanismi, attori. Bologna: Il Mulino.

DELLA PORTA, Donatella \& Alberto VANNUCCI. 1999. Corrupt Exchanges: Actors, resources, and mechanisms of political corruption. New York: Aldine de Gruyter.

DELLA PORTA, Donatella \& Alberto VANNUCCI. 2007. Mani Impunite: Vecchia e nuova corruzione in Italia. Roma/Bari: Laterza.

DELLA PORTA, Donatella \& Alberto VANNUCCI. 2012. The Hidden Order of Corruption: An Institutional Approach. Aldershot: Ashgate.

DELLA PORTA, Donatella \& Alberto VANNUCCI. 2021. La corruzione come sistema: Mecanisme, dinamiche, attori. Bologna: Il Mulino.

SMITH, Jackie, Marina KARIDES, Marc BECKER, Dorval BRUNELLE, Christopher CHASEDUNN, Donatella DELLA PORTA. 2007. Global democracy and the World Social Forum. Boulder Co.: Paradigm Publishers.

SMITH, Jackie, Marina KARIDES, Marc BECKER, Dorval BRUNELLE, Christopher CHASEDUNN, Donatella DELLA PORTA. 2014. Global democracy and the World Social Forum, $2^{\text {nd }}$ ed. London: Routledge. 


\section{AUTHOR INFORMATION}

Felippe CLEMENTE (ORCID iD: https://orcid.org/0000-0003-3465-9711) is a Postdoctoral Fellow at the Institute of Social Science, University of Lisbon (ICS-ULisboa). He got his PhD in Applied Economics at the Federal University of Viçosa, Brazil in 2016, with a thesis on Tax Evasion: Essays on Tax Evasion. He was recruited as an international researcher at Goethe Frankfurt University, Germany in 2015. He worked as research assistant at the Department of Applied Economics, Federal University of Viçosa, from 2016 to 2019. He was also junior professor at the Economics Department of the University of Viçosa for the period 2018/2019. His current research interests focus on corruption and economics crisis, tax evasion and economics of crime in Europe and abroad. felippe.clemente@ics.ulisboa.pt

Luís DE SOUSA (ORCID iD: https://orcid.org/0000-0002-6668-7138) is currently Research Fellow at the Institute of Social Sciences, University of Lisbon (ICS-ULisboa). He got his $\mathrm{PhD}$ in Social and Political Sciences at the European University Institute, Florence/Italy, on July 2012. His main research interests focus on corruption and corruption control studies, good governance, local government, regional integration, cross-border cooperation, comparative government and politics in Europe. He has several international peer reviewed publications on these topics. He also acts as a consultant to various international governmental and non-governmental organizations on corruption control issues. luis.sousa@ics.ulisboa.pt

Luciana Alexandra GHICA (ORCID iD: https://orcid.org/0000-0002-7973-7296) is associate professor within the Department of Comparative Governance and European Studies, Faculty of Political Science, University of Bucharest, where she also acts as founding director of the Centre for International Cooperation and Development Studies (IDC). She studied political science and international relations at the University of Bucharest, Central European University (Budapest, Hungary) and University of Oxford (UK). She specializes in the analysis of international cooperation processes, including international cooperation for development, with a focus on the institutional and discursive impact of democratization and democratic values on foreign policy and international politics. She edited the first Romanian encyclopedia of the European Union (three editions), co-edited the first Romanian handbook of security studies, and authored a monograph on the relations between Romania and the European Union, as well as several studies on foreign policy, international cooperation, and the dynamics of political science as a discipline. She did extensive fieldwork in Europe, Asia and Latin America, where she often interviewed scholars, politicians, representatives of governmental agencies, civil society activists and businesspeople. luciana.ghica@unibuc.ro

The authors contributed equally to the design of the interview and to the editorial review of the automatic transcript. The final version was reviewed and accepted by the interviewee.

\section{DECLARATION OF CONFLICTING INTERESTS}

The author(s) declared no potential conflicts of interest with respect to the research, authorship, and/or publication of this article.

\section{FUNDING}

This work was developed by Felippe CLEMENTE and Luis DE SOUSA as part of the research project EPOCA: Corrupção e crise económica, uma combinação perigosa: compreender as interacções processo-resultado na explicação do apoio à democracia (Ref.: PTDC/CPO-CPO/28316/2017), which received Portuguese national funding through the Fundação para a Ciência e Tecnologia (FCT).

Luciana Alexandra GHICA received no financial support for the research, authorship, and/or publication of this article.

Copyright (c) The Author(s), 2021. This is an Open Access article, distributed under the terms of the Creative Commons Attribution-NonCommercial-NoDerivatives 4.0 International License (http://creativecommons.org/licenses/by-nc-nd/4.0/). Anyone is free to read, download, copy, distribute, print, search, link, or link to the full text of this article, crawl the text for 
indexing, pass it as data to software, or use for any other lawful purpose, without asking prior permission from the publisher or the author, provided the original work is properly cited.

Published by Bucharest University Press. 